\title{
Antimicrobial and anti-inflammatory activity of four known and one new triterpenoid from Combretum imberbe (Combretaceae)
}

\author{
J.E. Angeh ${ }^{a}$, X. Huang ${ }^{b}$, I. Sattler ${ }^{b}$, G.E. Swan ${ }^{a}$, H. Dahse ${ }^{b}$, A. Härtl ${ }^{b}$ and J.N. Eloff $^{a}$ \\ ${ }^{a}$ Department of Paraclinical Science, Faculty of Veterinary Science, University of \\ Pretoria, Onderstepoort 0110, Pretoria, South Africa \\ ${ }^{\mathrm{b}}$ Leibniz Institute for Natural Product Research and Infection Biology, Beutenbergstrasse \\ 11a, D-07745 Jena, Germany
}

\begin{abstract}
Combretum imberbe is used widely in Africa inter alia for treating bacterial infections. In addition to four known triterpenoids, 1 $\alpha, 3 \beta$-dihydroxy-12-oleanen-29-oic (1), 1-hydroxy12-olean-30-oic acid (2), 3,30-dihydroxyl-12-oleanen-22-one (3), and 1,3,24-trihydroxyl12-olean-29-oic acid (4), a new pentacyclic triterpenoid (1 $\alpha, 23$-dihydroxy-12-oleanen29-oic acid-3 $\beta-O-2,4$-di-acetyl-1-rhamnopyranoside) $\mathbf{5}$ has been isolated through a bioassay-guided procedure from the leaves of Combretum imberbe. The structures of the compounds were elucidated on the basis of 1D and 2D NMR experiments, as well as mass spectrometric data. All compounds isolated had moderate $(62 \mu \mathrm{g} / \mathrm{ml})$ to strong (16 $\mu \mathrm{g} / \mathrm{ml})$ antibacterial activity (MIC values) against Staphylococcus aureus and Escherichia coli, with $\mathbf{1}$ and $\mathbf{5}$ being most active. Compounds $\mathbf{1}$ and $\mathbf{5}$ also showed very strong inhibition of $3 \alpha$-hydroxysteroid dehydrogenase with an $\mathrm{IC}_{50}$ of $0.3 \mu \mathrm{g} / \mathrm{ml}$. Compound 5 indicated a moderate anti-proliferative $\left(\mathrm{GI}_{50}=16.5\right.$ and $\left.13.2 \mu \mathrm{g} / \mathrm{ml}\right)$ and cytotoxic activity $\left(\mathrm{CC}_{50}=17.6 \mu \mathrm{g} / \mathrm{ml}\right)$ against K-562, L-929 and HeLa cell lines, respectively. The results of this study give credence to the ethnomedicinal use of Combretum imberbe and expand our knowledge on the biological activity of its metabolites.
\end{abstract}




\section{Article Outline}

1. Introduction

2. Materials and methods

2.1. General experimental procedures

2.2. Plant material

2.3. Extraction and isolation

2.4. Biological assays

2.4.1. Anti-microbial assays

2.4.2. Bioautography

2.4.3. Anti-inflammatory activity assay against $3 \alpha$-hydroxysteroid dehydrogenase

2.4.4. Cytotoxic and anti-proliferative efficacy

3. Results and discussion

4. Conclusion

Acknowledgements

References

\section{Introduction}

Combretaceae is a large family with at least 600 species. Combretum is one of the two most commonly occurring genera and widely used in African traditional medicine. The leaves of Combretum species are widely used for treating abdominal disorders (e.g. abdominal pains, diarrhea) backache, bilharziasis, chest coughs, colds, conjunctivitis, dysmenorrhoea, earache, fattening babies, fever, headache, hookworm, infertility in women, leprosy, pneumonia, scorpion and snake bite, swelling caused by mumps, syphilis, toothache and general weakness (Oliver-Bever, 1986 and Hutching et al., 1996). Preliminary work indicated that Combretum imberbe contains several antibacterial compounds (Eloff, 1999). Rogers and Subramony (1988) have isolated pentacyclic triterpenes acids from the leaves of this species, but did not investigate the biological activity. Rogers and Subramony (1988), as well as Katerere et al. (2003), have isolated related glycosides all based on the olean-12-29-oate aglycone (imberbic acid) from this 
plant. Earlier studies (Katerere et al., 2003) have shown that pentacyclic triterpenes from Combretum imberbe have antibacterial activity against Mycobacterium fortuitum. Despite the substantial phytochemical work reported on Combretum imberbe, the biological activities of compounds isolated from this plant have not been examined to a large extent for other activities that may be related to ethnomedicinal use. This paper also reports on anti-inflammatory, anti-proliferative, cytotoxic, as well as antibacterial activities of one new (5) and four known (1-4) pentacyclic triterpenes from Combretum imberbe.

\section{Materials and methods}

\subsection{General experimental procedures}

Column chromatography, silica gel 60M (230-400 mesh, Machery-Nagel, Germany), Sephadex LH-20 (Pharmacia Biotech AB, Sweden); TLC, silica gel plates (Sil G/UV $\mathrm{UV}_{254}$, $0.20 \mathrm{~mm}$, Machery-Nagel, Germany), spots were detected under a UV lamp and sprayed with vanillin $/ \mathrm{H}_{2} \mathrm{SO}_{4}$ spray reagent. Optical rotation, Propol digital automatic polarimeter (Dr. Wolfgang Kernchen GMBH, Germany); IR spectra, IFS55 spectrometer (Bruker, Germany); ${ }^{1} \mathrm{H}$ and ${ }^{13} \mathrm{C}$ NMR spectra, DPX-300, DNMR, DPX-500 (Bruker, Germany), measured in $\mathrm{CD}_{3} \mathrm{OD}$ or $\mathrm{CDCl}_{3}$ with reference against TMS (external); ESIMS, triple quadrupole mass spectrometer Quattro (VG Biotech, England); EIMS, $70 \mathrm{eV}$ direct inlet, high resolution with perfluorokerosine as a standard, MAT 95 XL (Finnegan, Germany).

\subsection{Plant material}

The leaves of Combretum imberbe were collected from National Botanical Garden in Nelspruit, South Africa in September 2002. The tree was identified by the curator for Combretaceae Mr Johan Hurter and by the tree label indicating origin and date collected. A voucher specimen is deposited in the Lowveld National Botanical Garden Herbarium, Nelspruit, South Africa.

\subsection{Extraction and isolation}

Air-dried and powdered leaves (500 g) of Combretum imberbe were defatted with hexane and extracted serially and exhaustively by maceration with dichloromethane (DCM), 
acetone and methanol (MeOH) to afford 18.2, 16.5, 25.5 and 41.5 $\mathrm{g}$ of $n$-hexane, DCM, acetone and $\mathrm{MeOH}$ soluble extracts, respectively. The DCM (16.5 g) extract was the most active extract (MIC $39 \mu \mathrm{g} / \mathrm{ml}$ against Staphylococcus aureus) was subjected to liquid-liquid fractionation (Eloff, 1998a) that afforded six fractions [chloroform $(6.5 \mathrm{~g})$, water (0.125 g), $n$-butanol (0.476 g), hexane (0.8), carbon tetrachloride (1.356 g), 35\% $\mathrm{H}_{2} \mathrm{O}$ in $\left.\mathrm{MeOH}(0.450 \mathrm{~g})\right]$. The chloroform fraction from the DCM extract (6.5 g), had an excellent antibacterial activity (MIC $10 \mu \mathrm{g} / \mathrm{ml}$ ) was chromatographed on a $2 \mathrm{~cm} \times 30 \mathrm{~cm}$ silica gel 60 open column using a stepwise gradient of $n$-hexane and increasing amounts of ethyl acetate (EtOAc) (20\% and $800 \mathrm{ml}$ each step), followed by EtOAc with increasing amounts of $\mathrm{MeOH}(10 \%$ and $800 \mathrm{ml}$ each step, ending at $40 \%)$. Collected fractions were evaporated under vacuum and examined by TLC. Fractions with a similar composition were pooled to give 12 major fractions $\left(F_{1}-F_{12}\right)$ that all had antibacterial activity. All tubes were filled with EtAOc and allowed to evaporate under a stream of cool air. Crystals were collected from $F_{2}$ and $F_{6}$ and washed with hexane to give $80 \mathrm{mg}$ of 1 and $7 \mathrm{mg}$ of 2 , respectively. $F_{1}(0.78 \mathrm{~g})$ was run on a $1 \mathrm{~cm} \times 20 \mathrm{~cm}$ silica gel 60 column to yield $7 \mathrm{mg}$ of $3 . F_{9}-F_{12}$ were further combined, dried by rotary evaporator to yield $F_{13}$ (3.2 g). $F_{13}$ was subjected to Sephadex LH20 $(3 \mathrm{~cm} \times 120 \mathrm{~cm}, \mathrm{MeOH})$ to yield six subfractions $F_{13.1}-F_{13.6}$. Sub-fractions $F_{13.4}$ and $F_{13.5}$ were combined $(0.3 \mathrm{~g})$ and subjected to silica gel $602 \mathrm{~cm} \times 30 \mathrm{~cm}$ column eluted with chloroform/methanol $(9: 11200 \mathrm{ml})$ to yield 4 (8 $\mathrm{mg})$ and $\mathbf{5}(6 \mathrm{mg})$.

\subsection{Biological assays}

\subsubsection{Anti-microbial assays}

The microplate serial dilution method (Eloff, 1998b) was used to determine the minimum inhibitory concentration (MIC) of fractions and pure compounds against Staphylococcus aureus ATCC 29213, Pseudomonas aeruginosa ATCC 27853, Enterococcus faecalis ATCC 29212 and Escherichia coli ATCC 25922. Extracts $(10 \mathrm{mg} / \mathrm{ml})$ or isolated compounds $(1 \mathrm{mg} / \mathrm{ml})$ were dissolved in acetone and serially diluted with sterile water in microplates in a laminar flow cabinet. The same volume of an actively growing culture of the test bacteria was added to the different wells and cultures were grown overnight in $100 \%$ relative humidity at $37^{\circ} \mathrm{C}$. The next morning tetrazolium violet was added to all 
the wells. Growth was indicated by a violet colour of the culture. The lowest concentration of the test solution that led to an inhibition of growth was taken as the MIC. The negative control acetone had no influence on the growth at the highest concentration used $(25 \%)$.

\subsubsection{Bioautography}

Bioautography (Begue and Kline, 1972) was used in the bioassay-guided isolation of antibacterial compounds and fractions. Developed chromatography plates ( $5 \mu \mathrm{lof}$ $10 \mathrm{mg} / \mathrm{ml}=50 \mu \mathrm{g}$ ) of extracts and fractions were dried over night and sprayed with a suspension of growing cells of the bacteria listed above and incubated at $37^{\circ} \mathrm{C}$ in a chamber at $100 \%$ relative humidity for $18 \mathrm{~h}$. After spraying with tetrazolium violet, clear zones on the chromatogram indicated inhibition of growth after incubating for $1 \mathrm{~h}$ at $37^{\circ} \mathrm{C}$.

\subsubsection{Anti-inflammatory activity assay against $3 \alpha$-hydroxysteroid dehydrogenase}

The assay on the inhibition of $3 \alpha$-hydroxysteroid dehydrogenase from rat liver cytosol was as according to Penning (1985). Increasing amounts of isolated compounds were added to the standard assay system, and the concentration of compound required to reduce the rate of $5 \beta$-dihydrocortisone reduction by $50 \%$ ( $\mathrm{IC}_{50}$ value) was determined from the resulting dose-response curves.

\subsubsection{Cytotoxic and anti-proliferative efficacy}

Isolated compounds were assayed on K-562 (DSM ACC 10) and L-929 (DSM ACC 2) cell line for their anti-proliferative and against HeLa (DSM ACC 57) for their cytotoxic activity as described by Dahse et al. (2000).

\section{Results and discussion}

After exhaustive extraction of the dried and powdered leaves of Combretum imberbe (500 g) with hexane, dichloromethane, acetone and methanol, bioautography against Staphylococcus aureus indicated that the highest number of antibacterial compounds were present in the DCM extract. Bioautography and MIC results indicated that the 
chloroform fraction after solvent/solvent fractionation of the DCM extract was the most active fraction (MIC $10 \mu \mathrm{g} / \mathrm{ml}$ ) with the highest number of antibacterial compounds. Exhaustive gradient column chromatography of the active chloroform fraction yielded twelve fractions that were all active against Staphylococcus aureus according to bioautography. Further chromatography of the fractions on silica gel 60 and Sephadex LH20 columns yielded five oleanene-type triterpenoids (1-5).

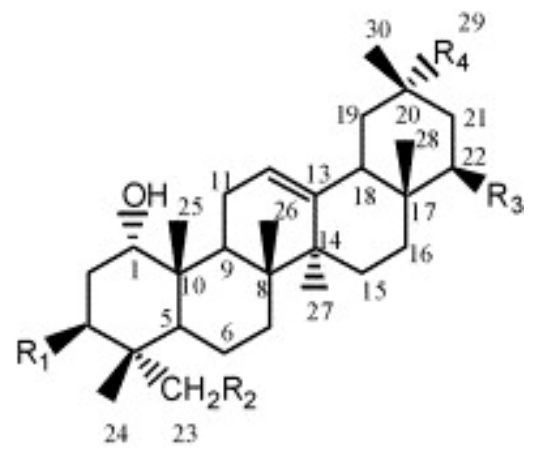

\begin{tabular}{|l|l|l|l|l|}
\hline Compounds & $\mathbf{R}_{\mathbf{1}}$ & $\mathbf{R}_{\mathbf{2}}$ & $\mathbf{R}_{\mathbf{3}}$ & $\mathbf{R}_{\mathbf{4}}$ \\
\hline $\mathbf{1}$ & $\mathrm{OH}$ & $\mathrm{H}$ & $\mathrm{H}$ & $\mathrm{COOH}$ \\
\hline $\mathbf{2}$ & $\mathrm{H}$ & $\mathrm{H}$ & $\mathrm{H}$ & $\mathrm{COOH}$ \\
\hline $\mathbf{3}$ & $\mathrm{H}$ & $\mathrm{H}$ & $=\mathrm{O}$ & $\mathrm{CH}_{2} \mathrm{OH}$ \\
\hline $\mathbf{4}$ & $\mathrm{H}$ & $\mathrm{H}$ & $\mathrm{OH}$ & $\mathrm{COOH}$ \\
\hline $\mathbf{5}$ & 2,4-Di-Ac-Rh & $\mathrm{OH}$ & $\mathrm{H}$ & $\mathrm{COOH}$ \\
\hline
\end{tabular}

IR spectra indicated the presence of olefinic $\left(1650 \mathrm{~cm}^{-1}\right)$ and hydroxyl $\left(3440 \mathrm{~cm}^{-1}\right)$ moieties in 1-5 and a carboxylic acid $\left(1680 \mathrm{~cm}^{-1}\right)$ in $\mathbf{1 , 2}, \mathbf{4}$ and $\mathbf{5} .{ }^{13} \mathrm{C}$ NMR spectra of $\mathbf{1}$ suggested an oleane skeleton with a carboxylic function, a trisubstituted double bond, two carbons bearing $\mathrm{OH}$ groups and an $\mathrm{AB}$ system as has been previously described from this species (Katerere et al., 2003). This pattern, along with similar ${ }^{1} \mathrm{H}$ NMR and mass spectrometric data, was also observed in compounds $\mathbf{2 - 4}$, suggesting a similar skeleton for all four compounds. The only difference between these three molecules could be observed in ring $\mathrm{A}$ and $\mathrm{E}$. According to a perfect match of the experimental data with the 
literature, they were identified as $1 \alpha, 3 \beta$-dihydroxy-12-oleanen-29-oic (1) (Katerere et al., 2003 and Rogers and Subramony, 1988), 1-hydroxy-12-olean-30-oic acid (2) (Mukherjee et al., 1994), 3,30-dihydroxyl-12-oleanen-22-one (3) (De Sousa et al., 1990) and 1,3,24trihydroxyl-12-olean-29-oic acid (4) (Duan and Takaihi, 2001), respectively. Compound 1 (imberbic acid) crystallized in most of the fractions and was isolated in large quantity $(80 \mathrm{mg})$. It has been previously isolated from the same species and appeared to be the major constituent in the leaves of Combretum imberbe. Compounds $\mathbf{2 ,} \mathbf{3}$ and $\mathbf{4}$ have been isolated from different plant species, but no biological activities were reported on them. Compound 5, a glycoside, was isolated and reported here for the first time.

Compound 5 was isolated as white crystals and has a molecular formula of $\mathrm{C}_{40} \mathrm{H}_{62} \mathrm{O}_{11}$ as determined by ${ }^{1} \mathrm{H},{ }^{13} \mathrm{C}$ NMR, DEPT data and HRESI data of a $\left[M+\mathrm{NH}_{4}\right]^{+}$ion peak $(\mathrm{m} / z$ 736.4613, calcd. 736, 4636). The IR spectrum indicated similar structural features as in compounds 1-4. ${ }^{1} \mathrm{H}$ NMR signals at $\delta_{\mathrm{H}} 5.25$ indicated a vinylic $\left(\mathrm{R}_{2} \mathrm{C}=\mathrm{CHR}\right)$ moiety and those at $\delta_{\mathrm{H}} 3.6$ and 3.7 hydroxylated methines in the aglycone. The signals at $\delta_{\mathrm{H}} 4.70$ and $\delta_{\mathrm{c}} 98.62$ indicated an anomeric $\mathrm{CH}$ group (acetal) of an oxygen-linked sugar moiety. The ${ }^{13} \mathrm{C}$ NMR data of 5 (Table 1) were almost identical to those of $1 \alpha, 3 \beta, 23$-trihydroxy-12oleanen-29-oic acid (Rogers and Subramony, 1988) except for an additional sugar moiety and the missing hydroxyl group at C-3 that had been replaced with the ether linked sugar moiety, as indicated by $\delta_{\mathrm{c}} 67.0$. The location of the new sugar moiety was confirmed by HMBC correlations between $\mathrm{H}-3$ and the anomeric carbon and between the anomeric proton and C-3. Two acetylated methines were indicated at $\delta_{\mathrm{c}} 75.4, \delta_{\mathrm{H}} 4.90\left(\mathrm{C}-4^{\prime}\right)$ and $\delta_{\mathrm{c}}$ $73.9, \delta_{\mathrm{H}} 5.11\left(\mathrm{C}-2^{\prime}\right)$ through correlations to two acetyl groups. All ${ }^{1} \mathrm{H}$ and ${ }^{13} \mathrm{C} \mathrm{NMR}$ data were assigned through HMQC, HMBC and COSY experiments.

Table 1.

${ }^{1} \mathrm{H}(300 \mathrm{MHz})$ and ${ }^{13} \mathrm{C}(75.4 \mathrm{MHz}) \mathrm{NMR}$ data of 5 in $\mathrm{CD}_{3} \mathrm{OD}$

\begin{tabular}{|l|l|l|}
\hline Position & ${ }^{\mathbf{1 3}} \mathbf{C}(\boldsymbol{\delta})$ & ${ }^{\mathbf{1}} \mathbf{H}(\boldsymbol{\delta}$, mult., $\boldsymbol{J}$ in Hz) \\
\hline C-1 CH & 72.6 & $3.55 \mathrm{t} \mathrm{br}$ \\
\hline $\mathrm{C}-2 \mathrm{CH}_{2}$ & 34.6 & $1.74 \mathrm{~m} ; 2.0, \mathrm{~m}$ \\
\hline $\mathrm{C}-3 \mathrm{CH}$ & 67.0 & $4.17 \mathrm{dd}(9.8,4.5)$ \\
\hline C-4 C & 43.2 & - \\
\hline
\end{tabular}




\begin{tabular}{|c|c|c|}
\hline Position & ${ }^{13} \mathrm{C}(\delta)$ & ${ }^{1} \mathbf{H}(\delta$, mult., $J$ in $\mathbf{H z})$ \\
\hline $\mathrm{C}-5 \mathrm{CH}$ & 41.3 & $1.75 \mathrm{~m}$ \\
\hline C- $6 \mathrm{CH}_{2}$ & 18.9 & $1.45 \mathrm{~m}, 1.54 \mathrm{~m}$ \\
\hline $\mathrm{C}-7 \mathrm{CH}_{2}$ & 33.0 & $1.30 \mathrm{~m}, 1.60 \mathrm{~m}$ \\
\hline $\mathrm{C}-8 \mathrm{C}$ & 40.7 & - \\
\hline $\mathrm{C}-9 \mathrm{CH}$ & 39.2 & $2.52 \mathrm{dd}(9.3,9.3)$ \\
\hline C-10 C & 41.8 & - \\
\hline $\mathrm{C}-11 \mathrm{CH}_{2}$ & 24.1 & $1.95 \mathrm{~m}$ \\
\hline $\mathrm{C}-12 \mathrm{CH}$ & 124.3 & $5.25 \mathrm{~s}$ \\
\hline C-13 C & 145.3 & - \\
\hline C-14 C & 43.5 & - \\
\hline $\mathrm{C}-15 \mathrm{CH}_{2}$ & 27.4 & $1.86 \mathrm{~m}$ \\
\hline $\mathrm{C}-16 \mathrm{CH}_{2}$ & 27.9 & $2.05 \mathrm{~m}$ \\
\hline $\mathrm{C}-17 \mathrm{C}$ & 33.5 & - \\
\hline $\mathrm{C}-18 \mathrm{CH}$ & 47.5 & $2.05 \mathrm{~m}$ \\
\hline $\mathrm{C}-19 \mathrm{CH}_{2}$ & 41.9 & $\mathrm{C}-1^{\prime} \mathrm{CH}$ \\
\hline $\mathrm{C}-20 \mathrm{C}$ & 43.6 & $\mathrm{C}-2^{\prime} \mathrm{CH}$ \\
\hline $\mathrm{C}-21 \mathrm{CH}_{2}$ & 30.4 & $\mathrm{C}-3^{\prime} \mathrm{CH}$ \\
\hline $\mathrm{C}-22 \mathrm{CH}_{2}$ & 37.0 & $\mathrm{C}-4^{\prime} \mathrm{CH}$ \\
\hline $\mathrm{C}-23 \mathrm{CH}_{3}$ & 12.6 & $\mathrm{C}-5^{\prime} \mathrm{CH}$ \\
\hline $\mathrm{C}-24 \mathrm{CH}_{2}$ & 70.6 & $\mathrm{C}-6^{\prime} \mathrm{CH}_{3}$ \\
\hline $\mathrm{C}-25 \mathrm{CH}_{3}$ & 17.3 & $\mathrm{C}-1^{\prime \prime} \mathrm{C}=\mathrm{O}$ \\
\hline $\mathrm{C}-26 \mathrm{CH}_{3}$ & 17.7 & $\mathrm{C}-2 " \mathrm{CH}_{3}$ \\
\hline $\mathrm{C}-27 \mathrm{CH}_{3}$ & 26.8 & $\mathrm{C}-3^{\prime \prime} \mathrm{C}=\mathrm{O}$ \\
\hline $\mathrm{C}-28 \mathrm{CH}_{3}$ & 28.6 & $\mathrm{C}-4^{\prime \prime} \mathrm{CH}_{3}$ \\
\hline $\mathrm{C}-29 \mathrm{CH}_{3}$ & 19.7 & $1.20 \mathrm{~s}$ \\
\hline
\end{tabular}




\begin{tabular}{|c|c|c|}
\hline Position & ${ }^{13} \mathrm{C}(\delta)$ & ${ }^{1} \mathrm{H}(\delta$, mult., $J$ in $\mathrm{Hz})$ \\
\hline $\mathrm{C}-30 \mathrm{C}$ & 182.8 & - \\
\hline $\mathrm{C}-1^{\prime} \mathrm{CH}$ & 98.6 & $4.60 \mathrm{~s} \mathrm{br}$ \\
\hline $\mathrm{C}-2^{\prime} \mathrm{CH}$ & 73.9 & $5.11 \mathrm{~m}$ \\
\hline $\mathrm{C}-3^{\prime} \mathrm{CH}$ & 68.8 & $4.11 \mathrm{dd}(3.5,9.8)$ \\
\hline $\mathrm{C}-4^{\prime} \mathrm{CH}$ & 75.4 & $4.90, \mathrm{dd}(9.8,9.8)$ \\
\hline $\mathrm{C}-5^{\prime} \mathrm{CH}$ & 67.6 & $3.81 \mathrm{~m}$ \\
\hline $\mathrm{C}-6^{\prime} \mathrm{CH}_{3}$ & 17.6 & $1.14 \mathrm{~d}(6.4)$ \\
\hline $\mathrm{C}-1^{\prime \prime} \mathrm{C}=\mathrm{O}$ & 172.2 & - \\
\hline $\mathrm{C}-2^{\prime \prime} \mathrm{CH}_{3}$ & 21.0 & $2.12 \mathrm{~s}$ \\
\hline $\mathrm{C}-3^{\prime \prime} \mathrm{C}=\mathrm{O}$ & 172.2 & - \\
\hline $\mathrm{C}-4^{\prime \prime} \mathrm{CH}_{3}$ & 20.8 & $2.08 \mathrm{~s}$ \\
\hline
\end{tabular}

$\delta$ values are expressed in ppm; ${ }^{1} \mathrm{H}\left(\mathrm{CD}_{3} \mathrm{OD}, 300 \mathrm{MHz}\right) ;{ }^{13} \mathrm{C}$ NMR $\left(\mathrm{CD}_{3} \mathrm{OD}, 75.4 \mathrm{MHz}\right)$.

According to the coupling constants and correlation peaks in NOESY spectrum, $\mathbf{5}$ had the same relative stereochemistry in the triterpenoid skeleton as $1 \alpha, 24 \beta$-dihydroxy-12oleanen-29-oic acid. The relative configuration of the chiral centres at C-1, C-3, C-4, C-8, C-15, C-20 and C-10 was determined by detailed NOESY analysis (Fig. 1). The rhamnose was determined to be attached as $\beta$ anomer on the basis of the ${ }^{13} \mathrm{C}$ NMR low field chemical shift of the anomeric carbon $\left(\delta_{\mathrm{C}} 98.6\right)$ and thus, together with biogenetic grounds, is assumed to be the 1-isomer (Seidel, 1999 and Rogers, 1989). Altogether,

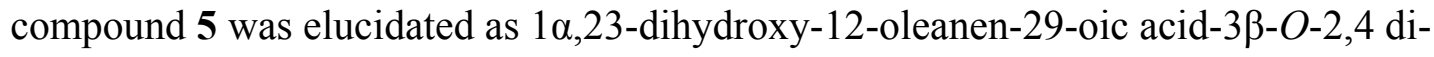
acetyl-1-rhamnopyranoside. This compound is reported here for the first time [white crystalline solid, $[\alpha]_{\mathrm{D}}{ }^{26}+36.6^{\circ}\left(\mathrm{CH}_{3} \mathrm{OH}, c 0.31\right)$. ESIMS: $m / z 718[M+\mathrm{Na}]^{+}$. IR $(\mathrm{KBr}$ pellet) $v_{\max }\left(\mathrm{cm}^{-1}\right) 3437,2949,1725,1647,1381,1225,1033,915,736$. NMR data see Table 1]. 


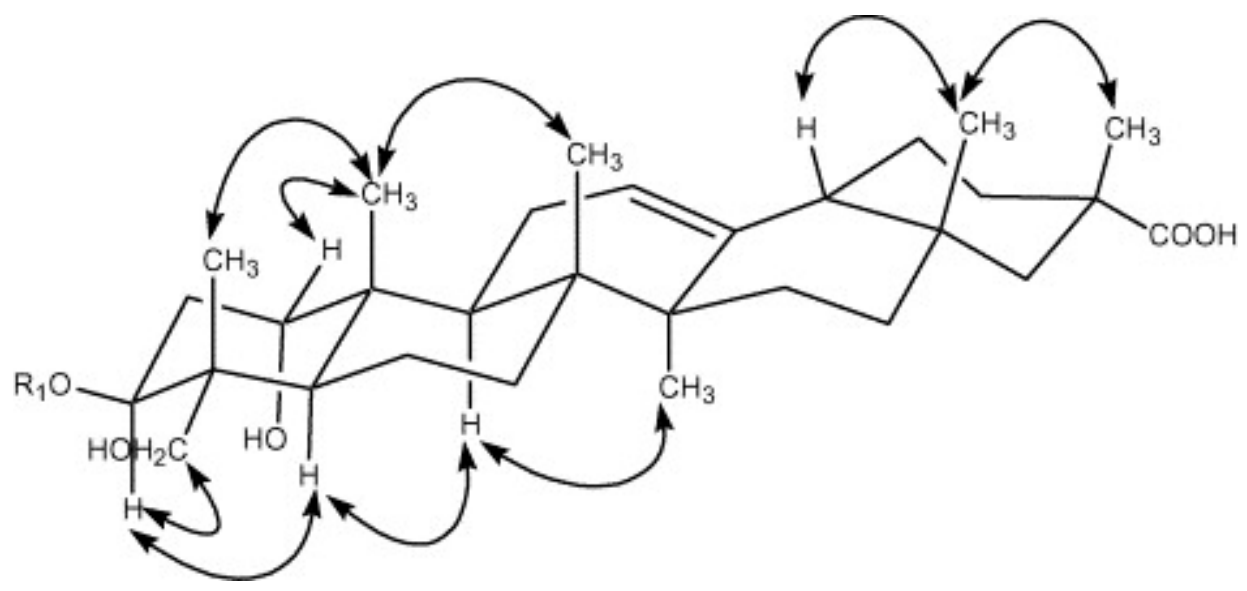

Fig. 1. NOE correlations in compound $\mathbf{5}$ as detected by NOESY data.

Regarding biological activity, pentacyclic and tetracyclic triterpenes are known for their action as molluscides (Marston and Hostettmann, 1985). Combretum molle with its molluscidal constituent, mollic acid, has been recommended for use in rural Africa to control schistosomiasis (Rogers, 1995). Arjunolic acid and arjungenin, arjunglucoside pentacylclic triterpenes have been isolated from Combretum molle (Panzini et al., 1993). All compounds isolated in this study were subjected to several assays for bioactivity profiling.

A serial microplate dilution assay (Eloff, 1998b) was used to screen for the antibacterial activity of the isolated compounds (Table 2). Compounds 1, 3, 4, and $\mathbf{5}$ had a similar activity $(16 \mu \mathrm{g} / \mathrm{ml})$ against Escherichia coli. This was despite the fact that Escherichia coli was resistant to oleanene type pentacyclic triterpenes isolated from the same plant species by Katerere et al. (2003). Against Staphylococcus aureus, $\mathbf{2}$ and $\mathbf{3}$ had an MIC of $93 \mu \mathrm{g} / \mathrm{ml}$ compared to $63 \mu \mathrm{g} / \mathrm{ml}$ for both 4 and 5 . The latter two compounds had hardly any activity against Enterococcus faecalis and $P$. aeruginossa. Compounds $\mathbf{4}$ and $\mathbf{5}$ might be the major antibacterial compounds against Escherichia coli and Staphylococcus aureus present in Combretum imberbe in consideration of their MIC values and bioautogram observation. The activity of the DCM extract (39 $\mu \mathrm{g} / \mathrm{ml})$ against Staphylococcus aureus was lower than that of the major compounds isolated. This may have resulted from synergistic effects of different antibacterial compounds or of antbacterial compounds and other compounds in the extract. Apart from our results there is limited data on the anti-microbial potential of the isoprenoid constituents of Combretaceae. Eloff (1999) had gathered preliminary data to indicate that crude extracts 
of Combretum imberbe and Combretum padoides are active against four nosocomial bacteria. Crude extracts of Combretum erythrophyllum are active against microbial cultures and contain up to 14 different antibacterial compounds (Martini and Eloff, 1998). Seven of these compounds were isolated and characterized as flavonoids with several biological activities (Martini et al., 2004a and Martini et al., 2004b). The activity of crude extracts support the use in traditional medicine for diseases caused by infective agents, e.g. bloody diarrhoea, wounds and conjunctivitis (Gelfand et al., 1985).

\section{Table 2.}

Minimum inhibitory concentration (MIC) in $\mu \mathrm{g} / \mathrm{ml}$ of compounds $\mathbf{1}-\mathbf{5}$ towards different pathogens [SA: Staphylococcus aureus (ATCC 29213); PA: Pseudomonas aeruginosa (ATCC 27853); EC: Escherichia coli (ATCC 25922); EF: Enterococcus faecalis (ATCC 29212)]

\begin{tabular}{|l|l|l|l|l|}
\hline Compounds & SA & EF & PA & EC \\
\hline $\mathbf{1}$ & 125 & 125 & $>250$ & 16 \\
\hline $\mathbf{2}$ & $94[44]$ & $24[11]$ & $>250$ & $>250$ \\
\hline $\mathbf{3}$ & 125 & 125 & $>250$ & 16 \\
\hline $\mathbf{4}$ & 63 & $>250$ & $>250$ & 16 \\
\hline $\mathbf{5}$ & 63 & $>250$ & $>250$ & 16 \\
\hline Gentamycin & 5.8 & 5.8 & 5.8 & 5.8 \\
\hline Acetone & $>25 \%$ & $>25 \%$ & $>25 \%$ & $>25 \%$ \\
\hline Standard & & & & \\
\hline
\end{tabular}

Standard deviation 0 except where indicated in brackets, cut off point $250 \mu \mathrm{g} / \mathrm{ml}$ for compounds and $25 \%$ for solvent negative control.

The anti-proliferative and cytotoxic efficacy of $\mathbf{1}, \mathbf{3}, \mathbf{4}$ and 5 was tested in vitro against L929, K-562 and HeLa cell lines, respectively (Table 3). Compound 3 had a strong and 5 a moderate activity against all three cell lines. In the testing on inhibition of $3 \alpha-$ hydroxysteroid dehydrogenase (Penning, 1985), $\mathbf{1}$ and $\mathbf{3}$ showed a strong activity $\left(\mathrm{IC}_{50}\right.$ of $0.30 \mu \mathrm{g} / \mathrm{ml}$ each), whereas 4 (>50 $\mu \mathrm{g} / \mathrm{ml}$ each) and $\mathbf{5}(16.5$ and $13.5 \mu \mathrm{g} / \mathrm{ml})$. 
Table 3 .

Cytotoxic and anti-proliferative activity of 1,3-5 with different cell lines

\begin{tabular}{|c|c|c|c|}
\hline \multirow[t]{2}{*}{ Compounds } & \multicolumn{2}{|c|}{ Anti-proliferative activity } & \multirow{2}{*}{$\begin{array}{l}\text { Cytotoxicity } \\
\text { HeLa CC }_{50}(\mu \mathrm{g} / \mathrm{ml})\end{array}$} \\
\hline & L-929 GI S0 $(\mu \mathrm{g} / \mathrm{ml})$ & K-562 GI $\mathrm{G}_{50}(\mu \mathrm{g} / \mathrm{ml})$ & \\
\hline 1 & 32.9 & 28.1 & 34.9 \\
\hline 3 & 9.0 & 8.7 & 10.5 \\
\hline 4 & $>50$ & $>50$ & 47.3 \\
\hline 5 & 16.5 & 13.5 & 17.5 \\
\hline Taxol & 0.1 & 0.01 & 0.01 \\
\hline
\end{tabular}

\section{Conclusion}

Triterpenoids of Combretum imberbe leaves had a reasonably antibacterial activity on Staphylococcus aureus, Escherichia coli, Enterococcus faecalis. It appears that the major antibacterial compounds were isolated, but the antibacterial activity of the crude extract was higher than could be extrapolated from the activity of the isolated compounds. This points to synergistic effects and justifies the use of Combretum imberbe extracts against bacterial infections. Several Combretum species had reasonable anti-inflammatory activity. The inhibition of $3 \alpha$-hydroxysteroid dehydrogenase activity of some of the isolated compounds confirms the tentative conclusion that the same compounds in Combretum species may be responsible for antibacterial and anti-inflammatory activity (Eloff et al., 2001).

\section{References}

Begue and Kline, 1972 W.J. Begue and R.M. Kline, The use of tetrazolium salts in bioautographic procedures, Journal of Chromatography 64 (1972), pp. 182-184. 
Dahse et al., 2000 H.M. Dahse, B. Schlegel and U. Grafe, Differentiation between inducers of apoptosis and non-specific cytotoxic drugs by means of cell analyser and immunoassay, Pharmazie 56 (2000), pp. 489-491.

De Sousa et al., 1990 J. De Sousa, G.D.F. Silva, J.L. Pedesl and R.J. Alves, Secomultiflorane-type triterpenoids acid s from Sandoricum koetjape, Phytochemistry 29 (1990), pp. 32-59.

Duan and Takaihi, 2001 H. Duan and H.M. Takaihi, Immunosuppresive terpenoids from extracts of Tripterygium wilfordi, Tetrahedron 57 (2001), pp. 8413-8424.

Eloff, 1998a J.N. Eloff, The presence of antibacterial compounds in Anthocleista grandiflora [Loganiaceae], South African Journal of Botany 64 (1998), pp. 209-212. Eloff, 1998b J.N. Eloff, A sensitive and quick microplate method to determine the minimum inhibitory concentration of plant extract for bacteria, Planta Medica 64 (1998), pp. 711-714.

Eloff, 1999 J.N. Eloff, The antibacterial activity of 27 South African members of the Combretaceae, South African Journal of Science 95 (1999), pp. 148-152.

Eloff et al., 2001 J.N. Eloff, A.K. Jäger and J. van Staden, The stability and relationship between anti-inflammatory activity and antibacterial activity of southern African Combretum species, South African Journal of Science 97 (2001), pp. 291-293.

Gelfand et al., 1985 M. Gelfand, S. Mavi, R.B. Drummond and B. Ndemera, The Traditional Medical Practitioner in Zimbabwe, Mambo Press, Gweru, Zimbabwe (1985). Hutching et al., 1996 A. Hutching, A.M. Scott, G. Lewis and A.M. Cumngham, Zulu Medicinal Plants. An Inventory, University of Natal Press, Pietermaritzburg, South Africa (1996).

Katerere et al., 2003 D.R. Katerere, A.I. Gray, R.J. Nash and R.D. Waigh, Anti-microbial activity of pentacyclic triterpenes isolated from African Combretaceae, Phytochemistry 63 (2003), pp. 81-88.

Martini and Eloff, 1998 N.D. Martini and J.N. Eloff, The preliminary isolation of several antibacterial compounds from Combretum erythrophyllum [Combretaceae], Journal of Ethnopharmacology 62 (1998), pp. 255-263. 
Martini et al., 2004a N.D. Martini, D.R. Katerere and J.N. Eloff, Seven flavonoids with antibacterial activity isolated from Combretum erythrophyllum, South African Journal of Botany 70 (2004), pp. 310-312.

Martini et al., 2004b N.D. Martini, D.R. Katerere and J.N. Eloff, Biological activity of five antibacterial flavonoids isolated from Combretum erythrophyllum (Combretaceae), Journal of Ethnopharmacology 93 (2004), pp. 207-212.

Marston and Hostettmann, 1985 B. Marston and K. Hostettmann, Plant mollucides, Phytochemistry 24 (1985), pp. 639-652.

Mukherjee et al., 1994 K.S. Mukherjee, G. Brahmachari and T.K. Mann, Triterpene from Limnophilia heterophylla, Phytochemistry 38 (1994), pp. 1273-1274.

Oliver-Bever, 1986 B. Oliver-Bever, Medicinal Plants in Tropical West Africa, Cambridge University Press, Cambridge (1986).

Panzini et al., 1993 I.P.F. Panzini, L. Verotta and C.B. Rogers, Constituents of the fruit of South African Combretum species, South African Journal of Science 89 (1993), pp. 324327.

Penning, 1985 T.M. Penning, Inhibition of $\beta$-dihydrocortisone reduction in rat liver cytosol: a rapid spectrophotometric screen for nonsteroidal anti-inflammatory drug potency, Journal of Pharmaceutical Sciences 74 (1985), pp. 651-653.

Rogers, 1995 C.B. Rogers, Acidic dammarane arabinofuranosides from Combretum rofundofollum, Phytochemistry 40 (1995), pp. 833-836.

Rogers, 1989 C.B. Rogers, New mono- and bidesmosidic triterpenoids isolated from Combretum padoides leaves, Journal of Natural Products 52 (1989), pp. 528-533.

Rogers and Subramony, 1988 C.B. Rogers and G. Subramony, The structure of imberbic acid, a 1-hydroxy pentacyclic triterpenoid from Combretum imberbe, Phytochemistry 27 (1988), pp. 531-553.

Seidel, 1999 Seidel, V. P.M., 1999. Phytochemical and Pharmocological studies on some species of Annonacease. Ph.D. Thesis. University of Strathclyde, UK.

Corresponding author. Tel.: +27 125298244 .

Corresponding author. Tel.: +493541656920. 